\title{
Biomass and Seed Yield of Maize with Effective Tillering Trait: CRTM-2
}

\author{
N. Jyothi Lakshmi*, P. Raghuram Reddy, Amol Patil, M. Vanaja, \\ K. Salini, B. Sarkar, S. S. Shishodia, S.K. Yadav, V. Maruthi, M. Maheswari, \\ K. Sammi Reddy and G. Ravindra Chary
}

Central Research Institute for Dryland Agriculture, Santhoshnagar, Hyderabad, India

*Corresponding author

\section{Keywords}

Tillering maize, Zea

luxuriance,

Effective tillers,

Effective cobs,

Biomass and seed yield

Article Info

Accepted:

18 May 2019

Available Online:

10 June 2019

\section{A B S T R A C T}

Maize genotype with effective tillers was developed from a natural mutant with ineffective tillers at Central Research Institute for Dryland Agriculture, Hyderabad, India. Teosinte (Zea mays ssp. luxurians), African tall (fodder maize) and Harsha (composite) were included for development of CRIDA tillering maize viz., CRTM-2. Single plant of CRTM2 had five effective tillers similar to Teosinte, with a total height of $1223.5 \mathrm{~cm}, 62.0$ leaves and 25.8 filled cobs. CRTM-2 showed an increase of 530.3, 423.7 and $2086.0 \%$ over Harsha, 388.0, 315.8 and $2350 \%$ over African tall and 15.5, 34.1 and $-53.0 \%$ over teosinte, for plant height, number of leaves and number of filled cobs respectively averaged over four seasons viz., 2016 (kharif and rabi), 2017 kharif and 2018 kharif. CRTM-2 had tillers like teosinte and the shape of cobs and seed type of maize. The percentage of superiority of CRTM-2 for seed yield /plant was $227.8 \%, 27.4 \%$ and $22.5 \%$ over Teosinte, African tall and Harsha respectively. It also showed superiority for total biomass. It was $102.7 \%, 21.5 \%$ and $63.5 \%$ over Teosinte, African tall and Harsha respectively. This tillering maize can be source material for innovative concept of developing new tillering maize varieties with effective cobs and significantly higher productivity and production of feed, fodder and food for animals, poultry and humans apart from industrial uses.

\section{Introduction}

Maize (Zea mays L.) is one of the most important crops in the world, being among the primary sources of human food, animal feed, and raw material for some industrial processes. Maize has wider adaptability under varied agro-climatic conditions. Wild species are important sources of genetic variability and may be exploited by breeding programs to introgress desirable traits. The potential use of
Teosinte in maize breeding has been evaluated since 1950s. Researchers concluded that Teosinte is a valuable germplasm for maize improvement, providing resistance to diseases and other abiotic stresses (Reeves, 1950), as well as quantitative traits (Cohen and Galinat, 1984; Casas et al., 2001). Some of the ancestral maize species have the prolificacy characteristics. Recently their architecture related to particular traits has been elucidated (Weber et al., 2008). Such studies suggested the relationship between specific gene and 
trait variation in Teosinte.

The annual teosinte, Zea mays ssp. luxurians, has tillering ability, having 6-7 tillers with tender stem, many small leaves and many very small cobs. It is highly palatable to the animals with high nutritive value. However the seeds are very hard, small sized and bitter in taste and low yielding. African tall is a tall, single stemmed, many leafed with white seeded cob and matures in 130-135 days. It produces higher green fodder yield and good silage can also be prepared from it. Maize composite variety Harsha is yellow-orange seeded, drought tolerant, high yielding and matures in 100-110 days.

Present study was aimed to develop tillering maize having more no. of tillers with effective cobs, more no. of leaves/plant and cobs with effective seeds from a natural mutant with ineffective tillers using Teosinte, African tall and Harsha.

\section{Materials and Methods}

A natural mutant with tillers was first identified in Hayathnagar Research Farm of CRIDA, Hyderabad during 1990. It had ineffective tillers (tillers with low height and ineffective cobs). To improve the number of effective tillers along with height it was crossed with teosinte. The progeny of natural mutant and teosinte was crossed with African tall to improve tiller height. The above progeny was crossed with Teosinte and African tall, using them as male parent was done in alternate seasons. After 4 years of above crossing, the progeny were crossed with normal maize (composite-harsha) and recurrent selection was followed and single plants were selected with desirable characteristics of higher number of tillers, tillers with effective cobs and normal maize type seed.

The crop was sown in kharif season during
June month in 2016, 2017 and 2018 and rabi season during November 2016. Teosinte, African tall and Harsha were sown along with CRTM-2 in all the seasons. The spacing was $75 \times 30 \mathrm{~cm}$ between rows and within a row respectively. Recommended dose of fertilizer for maize at the rate of 120:60:60 kg/ha of N, $\mathrm{P}_{2} \mathrm{O}_{5}$ and $\mathrm{K}_{2} \mathrm{O}$ was applied to the crop. Crop was maintained free from moisture stress, pests and diseases. Crop was grown in 3 replications. Each replication had 2 rows of 5 meter length. Crop duration of CRTM-2 was about 105-110 days. The checks Harsha and African tall matured in 110 and 135 days respectively.

At maturity, three plants of each genotype were used to determine above ground dry matter accumulation and seed yield. Plant height, number of leaves and no. of cobs were recorded. Dry weights were recorded after keeping the leaf, stem and tassel at $80^{\circ} \mathrm{C}$ for 48 hours in hot air oven. Cobs were sun dried. Total biomass and seed yield per plant was recorded.

\section{Results and Discussion}

The unique characters of CRTM-2, tillering maize developed at CRIDA is presented in figure 1 . The tillering maize showed five effective tall tillers apart from main stem and high number of leaves and filled cobs.

Anova for number of tillers, total plant height, number of leaves, number of cobs, total biomass and seed yield per plant in CRTM-2 and checks/parents, Teosinte, Harsha and African tall over mean data of four seasons viz; 2016k,2016R, 2017k and 2018k are presented in table 1 . The results revealed that CRTM-2 was significantly different from Teosinte, African tall and Harsha for all the characters studied. CRTM-2 had 5 tillers per plant as that of Teosinte. 
Fig.1 The tillers, leaves, cobs and seed of tillering maize CRTM-2

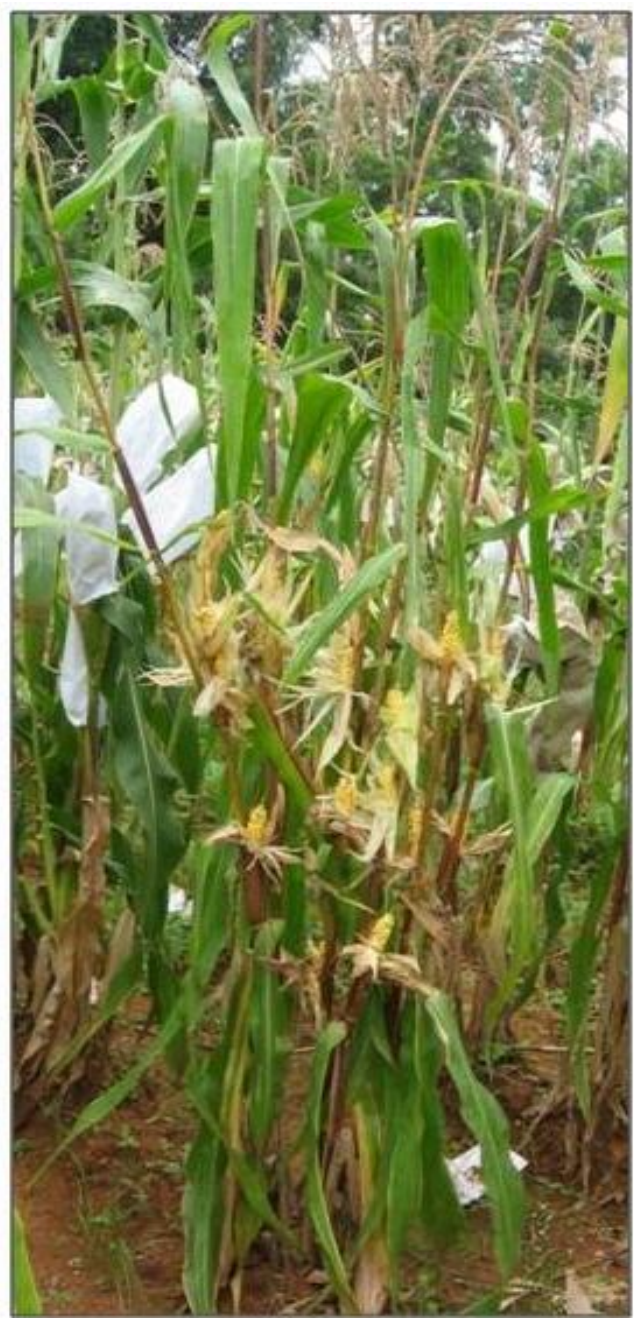

Table.1 Anova for No. of tillers, total plant height, No. of leaves, No. of cobs, total biomass and seed yield per plant in CRTM-2 and checks/parents, teosinte, harsha and African tall over mean data of four seasons viz; 2016k, 2016R, 2017k and 2018k.

\begin{tabular}{|c|c|c|c|c|}
\hline \multirow[t]{2}{*}{ Parameters } & \multicolumn{4}{|c|}{ Genotypes } \\
\hline & CRTM-2 & Teosinte & African tall & Harsha \\
\hline No. of tillers & 5 & 5 & - & - \\
\hline Plant Height (cm) & $1223.5^{\mathrm{a}}$ & $1057.3^{b}$ & $250.3^{c}$ & $194.8^{c}$ \\
\hline No. of leaves & $62.0^{\mathrm{a}}$ & $47.3^{b}$ & $15.0^{\mathrm{c}}$ & $11.9^{d}$ \\
\hline No. of filled cobs & $25.8^{\mathrm{a}}$ & $55.0^{b}$ & $1.1^{\mathrm{c}}$ & $1.2^{\mathrm{c}}$ \\
\hline Total biomass $(\mathrm{g} / \mathrm{pl})$ & $411.0^{\mathrm{a}}$ & $202.8^{d}$ & $338.4^{b}$ & $251.2^{c}$ \\
\hline Seed Yield(g/pl) & $132.1^{\mathrm{a}}$ & $40.3^{c}$ & $103.7^{b}$ & $107.8^{b}$ \\
\hline
\end{tabular}

Note: values followed by the same letter in a row are not significantly different at $\mathrm{P}=0.01$. 
Table.2 Number of tillers, height, number of leaves and number of filled cobs on main stem and tillers in CRTM-2 and its superiority over Teosinte, African tall and Harsha for four seasons viz., 2016k 2016R, 2017k and 2018k

\begin{tabular}{|c|c|c|c|c|c|c|c|c|c|c|c|c|c|c|c|}
\hline \multirow{2}{*}{$\begin{array}{c}\text { CRTM-2 } \\
\text { Main stem /Tiller }\end{array}$} & \multicolumn{5}{|c|}{ Height (cm) } & \multicolumn{5}{|c|}{ No. of leaves } & \multicolumn{5}{|c|}{ No. of filled cobs } \\
\hline & $\begin{array}{c}2016 \\
\mathrm{~K}\end{array}$ & $\begin{array}{c}2016 \\
\mathrm{R}\end{array}$ & $\begin{array}{c}2017 \\
\mathrm{~K}\end{array}$ & $\begin{array}{c}2018 \\
\mathrm{~K}\end{array}$ & Mean & $\begin{array}{c}2016 \\
\mathrm{~K}\end{array}$ & $\begin{array}{c}2016 \\
\mathrm{R}\end{array}$ & $\begin{array}{c}2017 \\
\mathrm{~K}\end{array}$ & $\begin{array}{c}2018 \\
\mathrm{~K}\end{array}$ & Mean & $\begin{array}{c}2016 \\
K\end{array}$ & $\begin{array}{c}2016 \\
\mathrm{R}\end{array}$ & $\begin{array}{l}201 \\
7 \mathrm{~K}\end{array}$ & $\begin{array}{l}201 \\
8 \mathrm{~K}\end{array}$ & $\begin{array}{l}\text { Mea } \\
\mathbf{n}\end{array}$ \\
\hline Main stem & 247 & 233 & 257 & 262 & 249.8 & 10 & 12 & 12 & 11 & 11.3 & 6 & 5 & 5 & 7 & 5.8 \\
\hline Tiller 1 & 217 & 231 & 241 & 248 & 234.3 & 10 & 10 & 11 & 11 & 10.5 & 4 & 3 & 8 & 5 & 5.0 \\
\hline Tiller 2 & 187 & 206 & 225 & 223 & 208.5 & 10 & 10 & 11 & 10 & 10.3 & 3 & 3 & 7 & 7 & 5.0 \\
\hline Tiller 3 & 180 & 175 & 210 & 215 & 196.8 & 10 & 10 & 11 & 10 & 10.3 & 3 & 5 & 3 & 3 & 3.5 \\
\hline Tiller 4 & 125 & 168 & 200 & 198 & 172.8 & 10 & 10 & 10 & 10 & 10.0 & 3 & 3 & 5 & 4 & 3.8 \\
\hline Tiller 5 & 109 & 155 & 192 & 190 & 161.5 & 10 & 10 & 9 & 10 & 9.8 & 1 & 2 & 4 & 4 & 2.8 \\
\hline Total & 1065 & 1168 & 1325 & 1336 & 1223.5 & 60 & 62 & 64 & 62 & 62.0 & 20 & 21 & 32 & 30 & 25.8 \\
\hline \multicolumn{16}{|l|}{ Checks/parents } \\
\hline \multicolumn{16}{|l|}{ Teosinte } \\
\hline & & & & & & & & & & & & & & & \\
\hline Main stem & 185 & 192 & 195 & 202 & 193.5 & 8 & 8 & 8 & 8 & 8.0 & 22 & 20 & 21 & 24 & 21.8 \\
\hline Tiller 1 & 180 & 187 & 190 & 197 & 188.5 & 8 & 8 & 8 & 8 & 8.0 & 7 & 7 & 7 & 7 & 7.0 \\
\hline Tiller 2 & 175 & 189 & 190 & 192 & 186.5 & 8 & 8 & 8 & 8 & 8.0 & 7 & 7 & 7 & 7 & 7.0 \\
\hline Tiller 3 & 169 & 181 & 180 & 186 & 179.0 & 8 & 7 & 8 & 8 & 7.8 & 7 & 7 & 7 & 7 & 7.0 \\
\hline Tiller 4 & 152 & 159 & 165 & 175 & 162.8 & 7 & 7 & 7 & 8 & 7.3 & 6 & 6 & 6 & 6 & 6.0 \\
\hline Tiller 5 & 143 & 146 & 142 & 157 & 147.0 & 7 & 7 & 7 & 8 & 7.3 & 6 & 6 & 6 & 6 & 6.0 \\
\hline Total & 1004 & 1054 & 1062 & 1109 & 1057.3 & 46 & 45 & 46 & 48 & 46.3 & 55 & 53 & 54 & 57 & 54.8 \\
\hline African tall & 233 & 243 & 255 & 270 & 250.3 & 15.5 & 15.5 & 14 & 14.8 & 15.0 & 1 & 1 & 1 & 1.2 & 1.1 \\
\hline Harsha & 175 & 176.5 & 197.8 & 230 & 194.8 & 11 & 11 & 13.3 & 12.2 & 11.9 & 1.2 & 1.3 & 1.3 & 1 & 1.2 \\
\hline \multicolumn{16}{|c|}{ \% inc. or dec. of CRTM-2 over } \\
\hline Teosinte & 6.1 & 10.8 & 24.8 & 20.5 & 15.5 & 30.4 & 37.8 & 39.1 & 29.2 & 34.1 & -63.6 & -60.4 & $\begin{array}{c}- \\
40.7\end{array}$ & $\overline{47.4}$ & $\begin{array}{c}- \\
53.0\end{array}$ \\
\hline African tall & 357.1 & 380.7 & 419.6 & 394.8 & 388.0 & 287.1 & 300.0 & 357.1 & 318.9 & 315.8 & 1900 & 2000 & $\begin{array}{c}310 \\
0\end{array}$ & $\begin{array}{c}240 \\
0\end{array}$ & $\begin{array}{c}235 \\
0\end{array}$ \\
\hline Harsha & 508.6 & 561.8 & 569.9 & 480.9 & 530.3 & 445.5 & 416.7 & 424.6 & 408.2 & 423.7 & 1567 & 1515 & $\begin{array}{c}236 \\
2\end{array}$ & $\begin{array}{c}290 \\
0\end{array}$ & $\begin{array}{c}208 \\
6\end{array}$ \\
\hline
\end{tabular}


Table.3 Total biomass and seed yield per plant of CRTM-2 and its superiority over checks/parents viz., Teosinte, African tall and Harsha for four seasons viz 2016k 2016R, 2017k and $2018 \mathrm{k}$

\begin{tabular}{|c|c|c|c|c|c|c|c|c|c|c|}
\hline CRTM-2 & \multicolumn{5}{|c|}{ Biomass (g/pl) } & \multicolumn{5}{|c|}{ Seed Yield (g/pl) } \\
\hline $\begin{array}{l}\text { Main stem } \\
\text { /Tiller }\end{array}$ & $\begin{array}{c}2016 \\
\text { K }\end{array}$ & $\begin{array}{c}2016 \\
\mathrm{R}\end{array}$ & $\begin{array}{c}2017 \\
\text { K }\end{array}$ & $\begin{array}{c}2018 \\
\mathrm{~K}\end{array}$ & Mean & $2016 K$ & $\begin{array}{c}2016 \\
\mathrm{R}\end{array}$ & $\begin{array}{c}2017 \\
\text { K }\end{array}$ & $\begin{array}{c}2018 \\
\mathrm{~K}\end{array}$ & Mean \\
\hline Main stem & 112.5 & 100.5 & 100.7 & 100.5 & 103.6 & 35.12 & 26.9 & 24.9 & 34 & 30.2 \\
\hline Tiller 1 & 68.3 & 67.3 & 86.7 & 78.1 & 75.1 & 23.8 & 19.1 & 34.7 & 30.1 & 26.9 \\
\hline Tiller 2 & 55 & 65.4 & 78 & 86.5 & 71.2 & 17.8 & 17.9 & 33.9 & 31.7 & 25.3 \\
\hline Tiller 3 & 51.6 & 72.8 & 50.9 & 51.4 & 56.7 & 16.046 & 28 & 13.7 & 16.4 & 18.5 \\
\hline Tiller 4 & 57.7 & 51 & 60.2 & 61.3 & 57.6 & 15.708 & 15.8 & 22 & 21 & 18.6 \\
\hline Tiller 5 & 38.9 & 41.5 & 46.4 & 60.9 & 46.9 & 5.112 & 9.7 & 15.4 & 19.6 & 12.5 \\
\hline Total & 384.0 & 398.5 & 422.9 & 438.7 & 411.0 & 113.6 & 117.4 & 144.6 & 152.8 & 132.1 \\
\hline \multicolumn{11}{|l|}{ Checks/parents } \\
\hline Teosinte* & 186.1 & 199.2 & 217.4 & 208.6 & 202.8 & 38.5 & 40 & 43.8 & 38.9 & 40.3 \\
\hline African tall & 321.0 & 323.8 & 357.4 & 351.4 & 338.4 & 91 & 95 & 116.9 & 112 & 103.7 \\
\hline Harsha & 225.5 & 246 & 274.3 & 259.2 & 251.3 & 91 & 101 & 121 & 118 & 107.8 \\
\hline \multicolumn{11}{|c|}{ \% inc. or dec. of CRTM-2 over } \\
\hline Teosinte & 106.3 & 100.1 & 94.5 & 110.3 & 102.7 & 195.6 & 193.5 & 230.1 & 292.8 & 227.8 \\
\hline African tall & 19.6 & 23.1 & 18.3 & 24.8 & 21.5 & 25.1 & 23.6 & 23.7 & 36.4 & 27.4 \\
\hline Harsha & 70.3 & 62.0 & 54.2 & 69.3 & 63.5 & 25.1 & 16.2 & 19.5 & 29.5 & 22.5 \\
\hline
\end{tabular}

CRTM-2 recorded $1223.5 \mathrm{~cm}, 62.0,25.8$, $411.0 \mathrm{~g} / \mathrm{pl}, 132.1 \mathrm{~g} / \mathrm{pl}$ for plant height, number of leaves, number of cobs, total biomass and seed yield respectively. The values of CRTM2 are significantly higher than Teosinte, African tall and Harsha for above characters mentioned except for no. of filled cobs over Teosinte.

Number of tillers, height, number of leaves and number of filled cobs on main stem and tillers in CRTM-2 and its superiority over Teosinte, African tall and Harsha for four seasons viz., 2016k, 2016R, 2017k and 2018k are presented in table 2. CRTM-2 showed an average height of $249.8 \mathrm{~cm}$ for main stem with a range of $161.5 \mathrm{~cm}$ to $234.3 \mathrm{~cm}$ in the height of five tillers. The total height of main stem and 5 tillers put together was $1223.5 \mathrm{~cm}$ while the checks Teosinte, African tall and Harsha recorded 1057.0, 250.3 and $194.8 \mathrm{~cm}$ respectively. The average no. of leaves was 11.3 on main plant with a range of 9.8 to 10.5 in five tillers. The total no. of leaves per plant was 62.0 while for checks it was $46.3,15.0$ and 11.9 for Teosinte, African tall and Harsha respectively. The average no. of filled cobs on the main plant was 5.8 in CRTM-2, while for the five tillers it ranged from 2.8-5.0 numbers with total no. of filled cobs for single plant being 25.8 while the checks Teosinte, African tall and Harsha recorded 55.0, 1.1 and 1.2 respectively.

The mean data for total biomass and seed yield over four seasons are given in table 3. CRTM-2 recorded an average biomass of $103.6 \mathrm{~g}$ for main stem with a range of $46.9 \mathrm{~g}$ to $75.1 \mathrm{~g}$ biomass for five tillers. The total biomass of main stem and 5 tillers put together was $411.0 \mathrm{~g} / \mathrm{plant}$ in CRTM-2 while the checks Teosinte, African tall and Harsha recorded 202.8, 338.4 and $251.3 \mathrm{~g} /$ plant respectively. The average seed yield was $30.2 \mathrm{~g}$ on main stem with a range of 12.5 to $26.9 \mathrm{~g}$ in five tillers. The total seed yield per plant was 132.1 for CRTM-2, while for checks it was 40.3, 103.7 and 107.8 for Teosinte, African tall and Harsha respectively. It is interesting to note at this 
stage that the cobs of Teosinte are too small in size while CRTM-2 had bigger size of cobs as evident from number of cobs and seed yield in teosinte $(54.8$ cobs and $40.3 \mathrm{~g} / \mathrm{pl})$ and CRTM-2 (25.8 cobs and $132.1 \mathrm{~g} / \mathrm{pl}$ ). CRTM-2 had seeds similar to maize.

The percentage of superiority of CRTM-2 over Teosinte, African tall and Harsha for plant height was $15.5 \%, 388.0 \%$ and $530.3 \%$ averaged over 4 seasons (Table 2). For number of leaves, the superiority of tillering maize was $34.1 \%, 315.8 \%$, and $423.7 \%$ over Teosinte, African tall and Harsha respectively. Similarly for no. of cobs the superiority of CRTM-2 over African tall and Harsha was $2350.0 \%$ and $2086.0 \%$ respectively. However there was decrease in number of cobs in CRTM-2 (-53.0\%) compared to Teosinte.

The percentage of superiority of CRTM-2 over Teosinte, African tall and Harsha for total biomass was 102.7, $21.5 \%$ and $63.5 \%$ while for seed yield/plant it was 227.8, 27.4\% and $22.5 \%$ respectively averaged over 4 seasons (Table 3).

The superiority of tillering maize, CRTM-2 for tillering trait, biomass and seed yield over the checks African tall and Harsha and with maize type cobs and seed reveals it to be very potential innovative genotype.

CRTM-2 can be source material for innovative concept of developing new tillering maize varieties with effective cobs for higher productivity of fodder, poultry feed and human food apart from industrial uses.

\section{References}

Casas SJF, Sánchez GJJ, Ramírez DJL, Ron PyS, Montes HJ. 2001. Rendimiento y sus componentes en retrocruzas maízteocintle. Revista Fitotecnia Mexicana 24, $17-26$.

Cohen JI, Galinat WC. 1984. Potential use of alien germplasm for maize improvement.

Crop Science 24, 1011-1015.

Doyle, J.J and Doyle J.L. Isolation of plant DNA from fresh tissue. Focus, v.12, p.13-15, 1990

Jaccard, P.1901 Etude comparative de la distribution florale dans une portion desalpes et des jura, Bull. Soc. Vaud. Sci. Nat. 37: 547-579.

Murray, H.G and W.F. Thompson, 1980 Rapid isolation of high molecular weight plant DNA, Nucleic. Acids. Res. 8: 4321-4325.

Perrier X., A. Flori and F. Bonnot, 2003 Data analysis methods, in: P. Hamon, M. Seguin, X. Perrier, J.C. Glaszmann (Eds.), Genetic Diversity of Cultivated Tropical Plants, Enfield, Science Publishers, Montpellier, pp. 43-76.

Reeves RG. 1950. The use of teosinte in the improvement of corn inbreds. Agronony Journal 42, 248-251.

Weber, A. L., William H.B., Rucker J., Baltazar M.B., J. de Jesus sanchezgonzalez, Feng P., Buckler E.S. and Doebley J., 2008 The Genetic Architecture of Complex Traits in Teosinte (Zea mays ssp. parviglumis): New Evidence From Association Mapping Genetics, 180: 1221-1232

\section{How to cite this article:}

Jyothi Lakshmi, N., P. Raghuram Reddy, Amol Patil, M. Vanaja, K. Salini, B. Sarkar, S.S. Shishodia, S.K. Yadav, V. Maruthi, M. Maheswari, K. Sammi Reddy and Ravindra Chary, G. 2019. Biomass and Seed Yield of Maize with Effective Tillering Trait: CRTM-2. Int.J.Curr.Microbiol.App.Sci. 8(06): 3355-3360. doi: https://doi.org/10.20546/ijcmas.2019.806.398 